\title{
The Effects of Lipophilic and Hydrophilic Statins on Bone Tissue Mineralization in Saos2 Human Bone Cell Line - In vitro Comparative Study
}

\section{Dolkart O, Pritsch T, Sharfman Z, Somjen D, Salai M, Maman E and Steinberg EL*}

Division of Orthopedic Surgery and Institute of Endocrinology, Metabolism and Hypertension, Tel- Aviv Sourasky Medical Center and the Sackler Faculty of Medicine, TelAviv University, Tel-Aviv, Israel

\begin{abstract}
We analyzed the effects of of commonly used statins that belong to lipophilic and hydrophilic groups on human osteoblastic cell activity in vitro, specifically proliferation and tissue mineralization. Proliferation and mineralisation assays were performed on the following drugs: rosuvastatin, atorvastatin, pravastatin, simvastatin and mevastatin. Cells were exposed to the drugs for $24 \mathrm{~h}$ and analyzed for DNA synthesis. Mineralization was analyzed after 21 days of drugs treatment. Rosuvastatin, atorvastatin, pravastatin and simvastatin stimulated DNA synthesis to different extents while mevastatin had no effect. The most effective drugs in terms of proliferation were rosuvastatin $(8 \mu \mathrm{g} / \mathrm{ml}$ by $219+25 \%)>$ pravastatin $(10 \mu \mathrm{g} / \mathrm{ml}$ by $185+16 \%)>$ atorvastatin $(10 \mu \mathrm{g} / \mathrm{ml}$ by $171+6 \%)>\operatorname{simvastatin}(30 \mu \mathrm{g} / \mathrm{ml}$ by $152+10 \%)$. Rosuvastatin inhibited mineralization by $57+3 \%$ and pravastatin stimulated it by $127+5 \%$, while all other compounds totally destroyed cells. Our results indicate that particular statins increase bone proliferation and bone mineralization in cell lines, suggesting a potential for these compounds to be beneficial in patients with established osteoporosis and and may enhance a fracture healing process. However, other statins may inhibit the mineralization process, and even induce cell death.
\end{abstract}

Keywords: Osteoporosis; Bone cell; Mineralization; DNA synthesis

\section{Introduction}

Bone strength is influenced by a number of different factors such as mass, size, geometry and micro-architecture. These include the mineralization of bone and the characteristics of the organic matrix (orientation and chemical structure of the collagen fibers), the accumulation of micro-damage, and indirectly the apoptosis of osteocytes [1-4]. Bone strength is robustly influenced by the rate of bone turnover [5]. The major role of mineralization has been emphasized by the fact that fracture risk and bone mineral density (BMD) were changed in osteoporotic patients treated with antiresorptive agents, without modifications of bone matrix volume or bone microarchitecture. This was mostly, due to the modifications of the duration of secondary mineralization [6-12].

Patients with osteoporosis lose more than $50 \%$ of bone mass at critical sites in the skeleton and, moreover, have marked disruption of trabecular bone micro-architecture [13]. Therefore, anabolic therapies are urgently needed to replace the lost bone mass and cure the prevailing disease conditions.

Hydroxy-methyl-glutaryl coenzyme A reductase (HMG-CoA) inhibitors (statins) are the most used drugs for treating hyperlipidemia and reducing the risk of coronary artery disease. Statins are subdivided into two classes: hydrophilic (pravastatin and rosuvastatin) and lipophilic (mevastatin, simvastatin and atorvastatin). In addition to their established cholesterol-lowering properties, statins, exert a number of cholesterol-independent, pleiotropic effects, including anti-inflammatory actions, immunomodulatory, antioxidant, antithrombotic, and endothelium-stabilizing properties [14,15]. Recent findings indicating their anabolic action on bone have spurred large interest among researchers and clinicians $[16,17]$.

The effects of the drugs were traditionally tested in the SaOS2 cellline. SaOS-2 ("sarcoma osteogenic") is a non-transformed cell line that had been derived from the primary osteosarcoma of an 11-year- old Caucasian girl in 1973 by Fogh et al. [18]. In 1987, Rodan et al. determined that SaOS-2 cells "possess several osteoblastic features and could be useful as a permanent line of human osteoblast-like cells and as a source of bone-related molecules" [19]. One of the advantages for using the SaOS- 2 cell line is that they can be fully differentiated in a manner that the osteoblastic cells do naturally, thus making these cells a valuable model for studying events associated with the late osteoblastic differentiation stage in human cells [20].

In the present study, we compared the effects of five currently available statins which belong to either group on bone mineralization in vitro.

\section{Materials and Methods}

Materials: Alizarin Red, Light Green and dexamethasone were obtained from Sigma Chemicals Co. (St. Louis, MO, USA). All drugs were obtained from Enzo Life Sciences (Enzo Life Sciences, Farmingdale, NY, USA). All other chemical used were of analytical grade.

\section{Cell cultures}

A SaOS2 human bone cell line was obtained from ATCC (Manassas, VA, USA) and grown in DMEM containing 10\% FBS,

*Corresponding author: Steinberg Eli L, MD, Division of Orthopedic Surgery, TelAviv Sourasky Medical Center; Tel- Aviv 64239, Israel, Tel: 972-3-6974720; Fax: 972-3-6973065; E-mail: steinberge@tlvmc.gov.il

Received April 24, 2015; Accepted April 27, 2015; Published May 04, 2015

Citation: Dolkart O, Pritsch T, Sharfman Z, Somjen D, Salai M, et al. (2015) The Effects of Lipophilic and Hydrophilic Statins on Bone Tissue Mineralization in Saos2 Human Bone Cell Line-In vitro Comparative Study. Pharm Anal Acta 6: 363. doi:10.4172/21532435.1000363

Copyright: $\odot 2015$ Steinberg EL, et al. This is an open-access article distributed under the terms of the Creative Commons Attribution License, which permits unrestricted use, distribution, and reproduction in any medium, provided the original author and source are credited. 
Citation: Steinberg EL, Dolkart O, Pritsch T, Sharfman Z, Somjen D, et al. (2015) The Effects of Lipophilic and Hydrophilic Statins on Bone Tissue Mineralization in Saos2 Human Bone Cell Line-In vitro Comparative Study. Pharm Anal Acta 6: 363. doi:10.4172/21532435.1000363

Page 2 of 4

according to the manufacturer's instructions. Cells were cultured without any stimulatory supplements or vitamins in Falcon flasks (BD Biosciences, San Jose, USA) in a humidified incubator at $37^{\circ} \mathrm{C}$, using a standard mixture of $95 \%$ air and $5 \% \mathrm{CO}_{2}$. Forty IU/ml of penicillin/ streptomycin/ampicillin was added to each medium [19].

Sub-confluent cultured cells were treated with vehicle; different doses of rosuvastatin, atorvastatin, pravastatin, simvastatin and mevastatin. The doses of each vehicle were designed to approximate the mean concentrations of therapeutic statins doses in human serum based on works from Keshitalo et. al., Stern et al. and Hamidi et al. [21-23]. The pleiotripic effects of statins have been detected at concentrations between 1-50 $\mu \mathrm{mol} \mathrm{L}^{-1}$ in vivo [24-28], thus in this study similar concentrations were used.

a. for 24 hours for DNA synthesis (DNA) as previously described [29] or

b. Cells were grown for 21 days in the presence of dexamethasone $10-8 \mathrm{M}$ (DEX), $50 \mu \mathrm{g} / \mathrm{ml}$ sodium L-ascorbate (vitamin C) and $10 \mathrm{mM}$ $\beta$-glycerophosphate. The growth medium was changed on day 4 and evidence of mineralization could be observed on day 14 .

\section{Assessment of DNA synthesis}

After hormonal treatment for 22 hours, ${ }^{3}[\mathrm{H}]$ thymidine was added for 2 hours and its incorporation into DNA was determined as previously described [29].

\section{Alizarin Red S staining protocol for calcium detection}

Alizarin Red $\mathrm{S}$ is an anthraquinone derivative used to identify calcium in biological tissues. Calcium forms an Alizarin Red S-Calcium complex and is stained red. After treatment, the cells were fixed with absolute methanol for 10 min and stained with Alizarin Red S for 1 min. The excess dye was washed with double-distilled water (DDW); cells were stained with Light Green and observed under a microscope [30].

\section{Quantitation of Mineralization of SaSO2}

Cells were grown in 6-well plates for 21 days, washed with DDW, fixed in $10 \%$ formaldehyde for $15 \mathrm{~min}$ at room temperature, washed (with DDW), and stained with Alizarin red at $40 \mathrm{mM}$ for $20 \mathrm{~min}$ at room temperature with gentle shaking. Extra dye was removed by DDW. Cells were observed microscopically and were frozen at $-20^{\circ} \mathrm{C}$ [29]. For the quantification of the dye, $800 \mu \mathrm{l} 10 \%$ acetic acid was added to each well, incubated at room temperature for $30 \mathrm{~min}$ with shaking, scraped off the wells and transferred to Eppendorf tubes, vortexed and heated at $85^{\circ} \mathrm{C}$ for $30 \mathrm{sec}$, cooled down and centrifuged at $20000 \mathrm{x} \mathrm{g}$ for $15 \mathrm{~min}$. The supernatant was transferred to new Eppendorf tubes, and $200 \mu \mathrm{l}$ of $10 \%$ ammonium hydroxide was added to each tube to adjust the $\mathrm{pH}$ to $4.1-4.5$, after which $150 \mu \mathrm{l}$ of the liquid were transferred to 96- well plates and the optical density (OD) at $405 \mathrm{~nm}$ was determined [30].

\section{Statistical analysis}

Statistical analyses were performed using SPSS version 21.0 software (SPSS, Chicago, IL). The values are expressed as mean \pm standard deviation (SD). $\mathrm{P} \leq 0.05$ was considered statistically significant. Analyses of variance (one way ANOVA) were used. When significant differences were found they were followed by Tukey HSD test for nonequal sample size for comparisons. When percentages were compared, before data were analyzed by ANOVA, they were subjected to an arcsin of square root-transformation for percentages and ratios to meet the criteria of the ANOVA method.

\section{Results}

All drugs tested stimulated significantly DNA synthesis to different extents. Rosuvastatin, Atorvastatin, Pravastatin and Simvastatin stimulated DNA synthesis in a decreasing order to different extents (Figure 1 and Figure 2) while mevastatin had no effect (Figure 1). The most effective was Rosuvastatin $(8 \mu \mathrm{g} / \mathrm{ml}$ by $219+25 \%)>$ Pravastatin $(10 \mu \mathrm{g} / \mathrm{ml}$ by $185+16 \%)$ (Figure 1$)>$ Atorvastatin $(10 \mu \mathrm{g} / \mathrm{ml}$ by $171+6 \%)>$ Simvastatin $(30 \mu \mathrm{g} / \mathrm{ml}$ by $152+10 \%)$ (Figure 2$)$. During cell mineralization analyzes, Rosuvastatin inhibited mineralization by $57+3 \%$ and Pravastatin stimulated it by $127+5 \%$ following 21 days of the exposure. Mevastatin, simvastatin and atorvastatin totally destroyed cells after $48 \mathrm{~h}$ of the treatment.

\section{Discussion}

We demonstrated herein, cells death in the presence of lipophilic

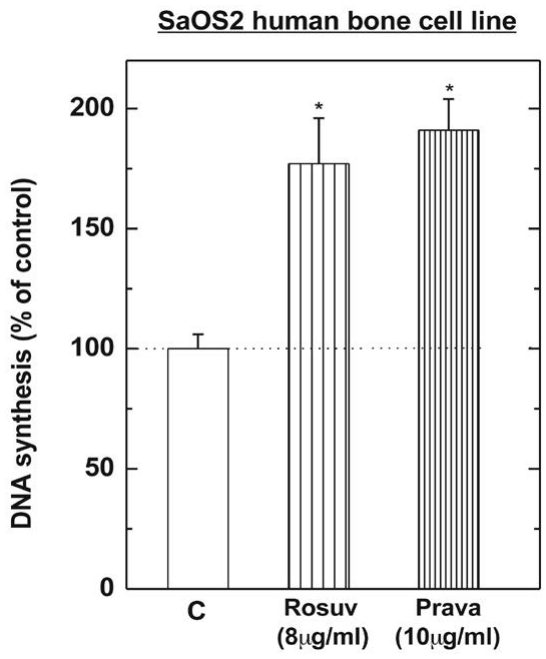

Figure 1: The effect of hydrophilic statins (rosuvastatin and pravastatin) on DNA synthesis in the human bone cell line SaOS2. Details are given in the experimental section. Results are expressed as \% change in DNA synthesis \pm SEM for $n=5-8$. ${ }^{*} p<0.05,{ }^{* *} p<0.01$. compared with vehicle control.

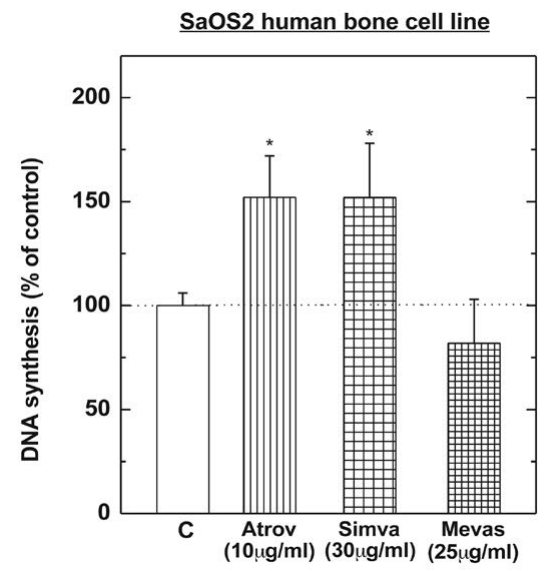

Figure 2: The effect of lipophilic (mevastatin, simvastatin and atorvastatin) on DNA synthesis in the human bone cell line SaOS2. Details are given in the experimental section. Results are expressed as \% change in DNA synthesis \pm SEM for $n=5-8 .{ }^{*} p<0.05,{ }^{* *} p<0.01$. Compared with vehicle control. 
Citation: Steinberg EL, Dolkart O, Pritsch T, Sharfman Z, Somjen D, et al. (2015) The Effects of Lipophilic and Hydrophilic Statins on Bone Tissue Mineralization in Saos2 Human Bone Cell Line-In vitro Comparative Study. Pharm Anal Acta 6: 363. doi:10.4172/21532435.1000363

Page 3 of 4

(i.e. mevastatin, simvastatin and atorvastatin) but not hydrophilic statins (i.e. rosuvastatin and pravastatin).

This phenomenon has been previously described in other in vitro systems where lipophilic but not hydrophilic statins induce apoptosis. Fromigue $\mathrm{O}$ et al. reported a high apoptotic rate induced by lipophilic statins in osteosarcoma cells [31]. Due to these findings, they even suggested that lipohilic statins at high doses and in combination with chemotherapeutics may be efficient in the treatment of osteosarcoma. Another study by Kato $S$ et al. [32], demonstrated that ovarian, endometrial and cervical cancer cells undergo apoptosis in the presence of lipophilic (i.e. lovastatin and simvastatin) but not hydrophilic statins (i.e. pravastatin).

Lipophilicity of statins improves drug access to different tissues [33]. Lipophilic statins achieve higher levels of exposure in non-hepatic tissues, while the hydrophilic statins are more hepatoselective [34, 35]. Thus, a differential effect of statins can be predicted among hepatic and non-hepatic tissues. Evidence from randomized controlled clinical trials and in vitro studies support this differential effect of statins depending on its class (lipophilic versus hydrophilic) and the specific tissue assayed [36-38].

Sugiyama et al. [39] investigated the influence of compactin, simvastatin, and pravastatin on osteoblast differentiation and bone formation in human osteosarcoma cells by measuring bone morphogenetic protein (BMP)-2 expression and activity. It is well known that BMP-2 plays an important role in osteoblast differentiation and bone formation [39]. Unlike our results, they found that lipophilic statins (compactin and simvastatin), but not pravastatin, selectively induce BMP-2 in osteoblastic cells by inhibiting HMG-CoA reductase.

Statins are among the most commonly prescribed drugs in the last 20 years. Following the treatment with the aforementioned statins, osteoblasts demonstrated significant modulation of proliferation and mineralization. The findings that pravastatin increase bone proliferation and bone mineralization in cell lines, may suggest that this compound, in appropriate doses, to be beneficial in patients with metabolic bone diseases such as osteoporosis or in a fracture healing process. Nevertheless, other statins such as rosuvastatin may negatively interfere with the mineralization process and even inhibit it. The exact mechanisms by which different statins enhance or inhibit osteoblast proliferation and mineralization are not completely clear. Future research should determine whether statins have a stimulatory or inhibitory influence on bone formation.

We are aware of several limitations of the current study. All of the experiments were conducted on SaOS2 cells, an osteosarcoma cell line derived from an 11-year-old girl. The fact that the origin of this cell-line is from a child may somewhat affect the ability to apply the results to patient group targeted in the research question (i.e., adults or aged). Yet, it should be noted that this cell line is used even in the research of agerelated co-morbidity states such as osteoporosis and atheroscleroticcardiovascular diseases [40]. The concentration of simvastatin vehicle used was outside the range of $1-50 \mu \mathrm{mol} \mathrm{L}^{-1}$ previously described. Moreover, in vitro drug administration studies may not accurately predict in-vivo interactions, for instance, if alternative metabolic or excretory routes play a major role in the clearance of the drug in-vivo. Indeed, a more solid relationship between the effects of the drugs we tested on bone can be established by additional in-vivo studies. Nevertheless, the importance of our in vitro approach should not be underrated since our results indicate direct rather than systemic effects of these drugs on osteoblasts. Additionally, in vitro studies concentrating on a single mechanism provide easily interpretable information, although they do neglect the interplay between various mechanisms influencing the kinetics in a whole organism.

\section{Conclusion}

Based on our and previously reported results, one could assume that statins, apart from their lipid lowering and other pleiotropic effects, have a great potential to influence and alter various bone related conditions such as metabolic bone disease, fracture healing processes and even malignances. Choosing appropriate statin group, optimizing of the administration route and dosage, will help to achieve their bone and condition-specific pharmacokinetics, allowing the most suitable treatment.

\section{References}

1. Currey JD (1975) The effects of strain rate, reconstruction and mineral content on some mechanical properties of bovine bone. J Biomech 8: 81-86.

2. Peterlik H, Roschger $P$, Klaushofer K, Fratzl P (2006) From brittle to ductile fracture of bone. Nat Mater 5: 52-55.

3. Seeman E, Delmas PD, Bone quality--the material and structural basis of bone strength and fragility, N Engl J Med, 354 (2006) 2250-2261.

4. Kruzic JJ, Ritchie RO (2008) Fatigue of mineralized tissues: cortical bone and dentin. J Mech Behav Biomed Mater 1: 3-17.

5. Dempster DW1 (2002) The impact of bone turnover and bone-active agents on bone quality: focus on the hip. Osteoporos Int 13: 349-352.

6. Boivin GY, Chavassieux PM, Santora AC, Yates J, Meunier PJ (2000) Alendronate increases bone strength by increasing the mean degree of mineralization of bone tissue in osteoporotic women. Bone 27: 687-694.

7. Nuzzo S, Peyrin F, Cloetens P, Baruchel J, Boivin G (2002) Quantification of the degree of mineralization of bone in three dimensions using synchrotron radiation microtomography. Med Phys 29: 2672-2681.

8. Boivin G, Lips P, Ott SM, Harper KD, Sarkar S, et al. (2003) Contribution of raloxifene and calcium and vitamin D3 supplementation to the increase of the degree of mineralization of bone in postmenopausal women. $\mathrm{J}$ Clin Endocrinol Metab 88: 4199-4205

9. Boivin G, Vedi S, Purdie DW, Compston JE, Meunier PJ (2005) Influence of estrogen therapy at conventional and high doses on the degree of mineralization of iliac bone tissue: a quantitative microradiographic analysis in postmenopausal women, Bone 36: 562-567.

10. Borah B, Ritman EL, Dufresne TE, Jorgensen SM, Liu S, et al. (2005) The effect of risedronate on bone mineralization as measured by micro-computed tomography with synchrotron radiation: correlation to histomorphometric indices of turnover, Bone 37: 1-9.

11. Borah B, Dufresne TE, Ritman EL, Jorgensen SM, Liu S, (2006) Long-term risedronate treatment normalizes mineralization and continues to preserve trabecular architecture: sequential triple biopsy studies with micro-computed tomography, Bone 39: 345-352.

12. Bauss F, Dempster DW (2007) Effects of ibandronate on bone quality: preclinical studies. Bone 40: 265-273.

13. Fast facts on osteoporosis. , National Osteoporosis Foundation. , 2005.

14. Davignon J (2004) Beneficial cardiovascular pleiotropic effects of statins. Circulation 109: III39-43.

15. Kwak B, Mulhaupt F, Myit S, Mach F (2000) Statins as a newly recognized type of immunomodulator. Nat Med 6: 1399-1402.

16. Benoit B, Gofton W, Beaulé PE (2009) Hueter anterior approach for hip resurfacing: assessment of the learning curve. Orthop Clin North Am 40: 357-363.

17. Kanazawa I (2009) [Usefulness of metformin in diabetes-related bone disease] Clin Calcium 19: 1319-1325.

18. Fogh J, Fogh JM, Orfeo T (1977) One hundred and twenty-seven cultured human tumor cell lines producing tumors in nude mice. J Natl Cancer Inst 59 : 221-226. 
Citation: Steinberg EL, Dolkart O, Pritsch T, Sharfman Z, Somjen D, et al. (2015) The Effects of Lipophilic and Hydrophilic Statins on Bone Tissue Mineralization in Saos2 Human Bone Cell Line-In vitro Comparative Study. Pharm Anal Acta 6: 363. doi:10.4172/21532435.1000363

19. Rodan SB, Imai Y, Thiede MA, Wesolowski G, Thompson D, et al. (1987) Characterization of a human osteosarcoma cell line (Saos-2) with osteoblastic properties. Cancer Res 47: 4961-4966.

20. Hausser HJ, Brenner RE (2005) Phenotypic instability of Saos-2 cells in longterm culture. Biochem Biophys Res Commun 333: 216-222.

21. Hamidi M, Zarei N, Shahbazi MA (2009) A simple and sensitive HPLCUV method for quantitation of lovastatin in human plasma: application to a bioequivalence study. Biol Pharm Bull 32: 1600-1603.

22. Keskitalo JE, Pasanen MK, Neuvonen PJ, Niemi M (2009) Different effects of the ABCG2 c.421C>A SNP on the pharmacokinetics of fluvastatin, pravastatin and simvastatin. Pharmacogenomics 10: 1617-1624.

23. Stern RH, Yang BB, Hounslow NJ, MacMahon M, Abel RB, et al. (2000) Pharmacodynamics and pharmacokinetic-pharmacodynamic relationships of atorvastatin, an HMG-CoA reductase inhibitor. J Clin Pharmacol 40: 616-623.

24. Bu DX, Tarrio M, Grabie N, Zhang Y, Yamazaki H, et al. (2010) Statininduced Kruppel-like factor 2 expression in human and mouse T cells reduces inflammatory and pathogenic responses, J Clin Invest, 120: 1961-1970.

25. Chow OA, von Kockritz-Blickwede M, Bright AT, Hensler ME, Zinkernagel AS (2010) Statins enhance formation of phagocyte extracellular traps, Cell Host Microbe, 8: 445-454

26. Kureishi Y, Luo Z, Shiojima I, Bialik A, Fulton D, et al. (2000) The HMG-CoA reductase inhibitor simvastatin activates the protein kinase Akt and promotes angiogenesis in normocholesterolemic animals. Nat Med 6: 1004-1010.

27. Weitz-Schmidt G, Welzenbach K, Brinkmann V, Kamata T, Kallen J, et al (2001)Statins selectively inhibit leukocyte function antigen-1 by binding to a novel regulatory integrin site, Nat Med, 7 687-692.

28. Youssef S, Stuve O, Patarroyo JC, Ruiz PJ, Radosevich JL, et al. (2002) The HMG-CoA reductase inhibitor, atorvastatin, promotes a Th2 bias and reverses paralysis in central nervous system autoimmune disease, Nature, 420 78-84.

29. Somjen D, Kohen F, Lieberherr M, Gayer B, Schejter E, et al. (2005) Membrana effects of phytoestrogens and carboxy derivatives of phytoestrogens on human vascular and bone cells: new insights based on studies with carboxy-biochanin A. J Steroid Biochem Mol Biol 93: 293-303.
30. Katzburg S, Lieberherr M, Ornoy A, Klein BY, Hendel D, et al. (1999) Isolation and hormonal responsiveness of primary cultures of human bone-derived cells: gender and age differences. Bone 25: 667-673.

31. Fromigue O, Hay E, Modrowski D, Bouvet S, Jacquel A, et al. (2006) RhoA GTPase inactivation by statins induces osteosarcoma cell apoptosis by inhibiting p42/p44-MAPKs-Bcl-2 signaling independently of BMP-2 and cell differentiation, Cell Death Differ 13: 1845-1856.

32. Kato S, Smalley S, Sadarangani A, Chen-Lin K, Oliva B, et al. (2010) Lipophilic but not hydrophilic statins selectively induce cell death in gynaecological cancers expressing high levels of HMGCoA reductase. J Cell Mol Med 14: 1180-1193.

33. Hamelin BA, Turgeon J (1998) Hydrophilicity/lipophilicity: relevance for the pharmacology and clinical effects of HMG-CoA reductase inhibitors. Trends Pharmacol Sci 19: 26-37

34. Pfefferkorn JA, Song Y, Sun KL, Miller SR, Trivedi BK, (2007) Design and synthesis of hepatoselective, pyrrole-based HMG-CoA reductase inhibitors, Bioorg Med Chem Lett 17: 4538-4544.

35. White CM (1999) Pharmacological effects of HMG CoA reductase inhibitors other than lipoprotein modulation. J Clin Pharmacol 39: 111-118.

36. Cafforio P, Dammacco F, Gernone A, Silvestris F (2005) Statins activate the mitochondrial pathway of apoptosis in human lymphoblasts and myeloma cells. Carcinogenesis 26: 883-891.

37. Karp I, Behlouli H, Lelorier J, Pilote L (2008) Statins and cancer risk. Am J Med 121: 302-309.

38. Katz MS1 (2005) Therapy insight: Potential of statins for cancer chemoprevention and therapy. Nat Clin Pract Oncol 2: 82-89.

39. Sugiyama M, Kodama T, Konishi K, Abe K, Asami S, et al. (2000) Compactin and simvastatin, but not pravastatin, induce bone morphogenetic protein-2 in human osteosarcoma cells. Biochem Biophys Res Commun 271: 688-692.

40. Klein BY, Rojansky N, Ben-Yehuda A, Abou-Atta I, Abedat S, et al. (2003) Cell death in cultured human Saos2 osteoblasts exposed to low-density lipoprotein. J Cell Biochem 90: 42-58. 